\title{
KOMODIFIKASI SIARAN OLAHRAGA DI TELEVISI PUBLIK: STUDI KASUS LIGA PRIMER INGGRIS DI LPP TVRI
}

\author{
Dhyayi Warapsari ${ }^{1}$, Lintang Ratri Rahmiaji ${ }^{2}$, Ade Armando ${ }^{3}$ \\ 11dhyayi.warapsari@gmail.com, ${ }^{2}$ lintangratri84@gmail.com, ${ }^{3}$ armandoade@gmail.com \\ Program Studi Magister Ilmu Komunikasi FISIP Universitas Diponegoro
}

\begin{tabular}{ll} 
Article Info \\
\hline Commodification; TVRI; & Public \\
Service Broadcasting & (PSB); \\
English Premier League &
\end{tabular}

\section{PENDAHULUAN}

Olahraga dan media telah lama memiliki hubungan yang saling menguntungkan (Bellamy, 2006; Taylor \& Thomass, 2017). Olahraga dapat menyediakan konten yang mampu membantu media menjangkau khalayak yang diinginkan dan sulit dijangkau, sedangkan media dapat membantu olahraga tetap memiliki kedudukan yang penting secara kultural di tengah masyarakat dan dapat memberikan dunia olahraga keuntungan yang semakin besar (Bellamy, 2006). Hal itu mendorong proses komodifikasi olahraga dalam media.

Menurut Bellamy (2006), hubungan simbiosis antara olahraga dan media semakin berkembang seiring dengan perkembangan televisi, mulai dari televisi analog, televisi digital, hingga siaran televisi streaming yang dapat ditonton di telepon genggam. Kemunculan teknologi baru di dunia penyiaran (broadcasting), seperti transmisi satelit dan digital, memungkinkan peningkatan jumlah saluran siaran yang dapat secara

\begin{abstract}
Sport and media have a long history of mutually beneficial relationship. Sport has become a commodity. Private televisions use sport programs to gain more profits through various methods, such as advertising and paid subscription. The potential casters to get the broadcasting rights and thus drive the broadcasting rights fees higher every season. In 2019, TVRI with limited annual budget can acquire English Premier League broadcasting rights through partnership with Mola TV. TVRI as a public service broadcaster is not allowed to be profit-oriented like private televiliterature, with study case of English Premier League. Data are collected from and profits through various sport programs - similar to private televisions, but with some limitations that public television has.
\end{abstract}

Copyright (C) 2021 Interaksi: Jurnal Ilmu Komunikasi. simultan bersiaran dalam waktu panjang dengan jangkauan yang lebih luas (Milne, 2016). Hal itu menyebabkan ada lebih banyak slot waktu siaran yang harus diisi.

Program siaran olahraga menjadi pilihan untuk mengisi waktu siaran televisi karena dirasa memiliki beberapa keuntungan dibandingkan dengan programprogram siaran lainnya, antara lain karena keefisienan biaya, jadwal yang rutin, dan dapat memberikan hiburan penuh kejutan dan ketegangan yang disenangi publik (Bellamy, 2006). Siaran olahraga mampu menarik minat banyak khalayak untuk menonton televisi (Milne, 2016). Siaran-siaran olahraga populer dapat menarik khalayak dengan demografi yang akurat secara lebih efisien dan konstan dibandingkan dengan banyak genre lainnya (Milne, 2016). Program siaran olahraga juga memiliki kemampuan untuk diterima secara global melintasi batasan geografis dan budaya karena olahraga memiliki nilai-nilai universal yang mudah dipahami oleh penonton tanpa harus memiliki 
kemampuan literasi olahraga yang tinggi sehingga program siaran olahraga dapat didistribusikan secara global dengan sedikit modifikasi yang tidak memerlukan biaya yang besar (Bellamy, 2006).

Kemampuan-kemampuan yang dimiliki oleh siaran olahraga tersebut menjadikannya sebuah cara praktis bagi para pengiklan dan sponsor untuk menjangkau banyak khalayak (Milne, 2016). Pada momen pertandingan-pertandingan olahraga dengan rating dan share tinggi, seperti Piala Dunia dan Asian Games 2018, para pengiklan dan sponsor berlomba untuk memasang iklan secara gencar (Lubis, 2018).

Potensi keuntungan dari siaran olahraga itu mendorong banyak penyiar (broadcasters) bersaing untuk mendapatkan hak siar ajang pertandinganpertandingan olahraga besar dan populer (Milne, 2016). Persaingan tersebut meningkatkan nilai hak siar dan memberikan kekuatan yang signifikan kepada pemilik liga dan federasi olahraga untuk mengatur pasar (Milne, 2016).

Dilihat dari aspek nilai hak siar, salah satu pertandingan olahraga yang paling menguntungkan di dunia adalah Liga Primer Inggris (Milne, 2016). Berdasarkan nilai hak siar domestik musim 2016-2019, Liga Primer Inggris menempati posisi kedua paling menguntungkan setelah Liga American Football (National Football League / NFL) (Milne, 2016). Pada musim pertandingan 2019-2022, total nilai hak siar Liga Primer Inggris untuk pasar domestik dan internasional meningkat hampir delapan persen menjadi 9,2 miliar pound sterling atau sekitar 167 triliun rupiah (The Associated Press, 2019). Kenaikan tersebut didorong oleh kenaikan biaya sebesar tiga puluh persen yang harus dibayarkan oleh penyiar internasional untuk setiap pertandingan (The Associated Press, 2019).

Pada tahun 2019, TVRI mendapatkan hak siar untuk menayangkan Liga Primer Inggris musim pertandingan 2019/2020 (Soenarso, 2019). Hak siar tersebut diperoleh dari hasil kerja sama TVRI dengan Mola TV yang merupakan pemegang hak siar Liga Primer Inggris di Indonesia hingga tahun 2022 (Soenarso, 2019). Keberhasilan TVRI mendapatkan hak siar Liga Primer Inggris di tengah keterbatasan anggaran yang dimiliki oleh TVRI itu mengejutkan sejumlah pihak (Dhyaksa, 2019; Husaini, 2019).

Berbeda dengan televisi-televisi swasta komersial, TVRI sebagai sebuah Lembaga Penyiaran Publik (LPP) tidak diperkenankan untuk berorientasi komersial. Berdasarkan Peraturan Pemerintah Nomor 13 Tahun 2005, TVRI dapat menerima pendanaan dari iklan, tetapi iklan tersebut memiliki tarif yang dibatasi sesuai dengan Peraturan Pemerintah Nomor 33 Tahun 2017. Menurut PP No. 33 Tahun 2017 itu, tarif iklan spot tv komersial (TVC / Television Commercial) 30 detik di TVRI untuk penyiaran nasional analog per 30 detik adalah Rp2.000.000, sedangkan untuk siaran digital sebesar Rp.170.000. Tarif tersebut jauh berbeda dengan tarif iklan di televisi swasta yang dapat mencapai Rp65 juta per 30 detik (Puspa, 2019).

Komodifikasi siaran olahraga, seperti Liga Primer Inggris, di televisi-televisi komersial berkaitan dengan keuntungan yang didapatkan oleh penyiar dari iklan dan keuntungan langsung dari penonton yang membayar biaya berlangganan atau akses ke konten (Milne, 2016). Dalam kasus TVRI sebagai sebuah lembaga penyiaran publik, TVRI tidak dapat mengambil banyak keuntungan dari iklan ataupun langsung dari penonton seperti halnya televisi komersial sehingga muncul pertanyaan mengenai bagaimana bentuk komodifikasi siaran olahraga Liga Primer Inggris di LPP TVRI?

\section{KAJIAN PUSTAKA}

State of The Art

Komodifikasi di industri media masih menjadi permasalahan utama dalam pendekatan ekonomi politik media, mulai dari komodifikasi isi yang banyak dikaji seperti komodifikasi konten pernikahan "Janji Suci Rafi Nagita” (Enga, 2017) yang sampai tahun 2021 masih bertahan dan menginsipirasi me too program lainnya seperti keluarga Ruben Onsu dan keluarga Baim Wong. Komodifikasi juga sampai pada isu pekerja di industri media baru, yakni riset tentang komodifikasi youtuber pemula dan underrated (Ulya, 2019).

Riset yang mengkaji komodifikasi pada konteks olahraga di media relatif terbatas, namun setidaknya ada lima penelitian sebelumnya terkait isu olahraga 
khususnya sepakbola dalam pendekatan ekonomi politik media sejak tahun 2015-2020. Dua diantaranya meneliti komodifikasi di media cetak, yakni Komodifikasi Bonek di Harian Jawa Pos (Junaedi dkk, 2018) dam Komodifikasi Madura United FC di Kabar Madura (Rahardjo, 2018), keduanya menjadikan kesebelasan olahraga menjadi komoditas baik isi maupun pekerja di dalam pemberitaan karena kepemilikan horisontal. Sementara tiga riset lainnya meneliti tentang konten olahraga di televisi, yakni riset mengenai komodifikasi konten konflik sepakbola (Putra dkk, 2016) lalu tinjauan makro tentang sepakbola Indonesia di penyiaran (Dhyatmika, 2015) dan riset terbaru adalah tentang praktik ekonomi politik media pada tayangan Liga Inggris di TVRI (Sanjaya, 2020).

Penelitian ini berfokus pada proses komodifikasi isi siaran olahraga khususnya Liga Inggris di TVRI yang kemudian membedakannya dari penelitian sebelumnya.

\section{Metodologi}

Penelitian ini menggunakan metode penelitian kualitatif. Data dikumpulkan melalui studi kepustakaan dengan penelusuran dokumen berupa regulasi, artikelartikel daring, dan hasil wawancara wartawanwartawan media daring dengan Direktur Utama TVRI Helmy Yahya yang dilakukan oleh Azis Husaini dari Kontan.co.id (Husaini, 2019) dan Andya Dhyaksa dari beritagar.id (Dhyaksa, 2019). Untuk melengkapi penelitian ini, data juga dikumpulkan dari hasil observasi selama penayangan siaran Liga Primer Inggris di TVRI. Kemudian, data yang terkumpul dianalisis menggunakan pendekatan ekonomi politik. Ekonomi politik adalah studi yang mempelajari relasi sosial yang membentuk produksi, distribusi, dan konsumsi sumber daya, termasuk sumber daya komunikasi (Mosco, 2009). Berdasarkan definisi tersebut, penggunaan pendekatan ekonomi politik berarti melihat relasi kuasa di balik operasi bisnis komunikasi yang memengaruhi produk-produk komunikasi yang tersedia di pasar.

\section{Kajian Konseptual}

\section{Komodifikasi}

Komodifikasi adalah satu dari tiga titik awal kerangka konseptual dalam ekonomi politik komunikasi. Menurut Vincent Mosco (2009), komodifikasi adalah proses mentransformasikan suatu hal yang dinilai berdasarkan kegunaannya (nilai guna) menjadi suatu produk yang dapat dipasarkan dan dinilai berdasarkan apa yang produk itu dapat berikan pada proses pertukaran di pasar (nilai tukar).

Hubungan antara komodifikasi dan komunikasi dapat dilihat dari dua dimensi. Dimensi pertama dilihat dari kontribusi proses dan teknologi komunikasi terhadap proses komodifikasi (Mosco, 2009). Sebagai contoh, kemunculan internet membuka kesempatan perusahaan media untuk menyebarkan konten ke seluruh dunia melalui situs web dan memungkinkan mereka untuk memonitor konten mana yang paling digemari oleh khalayak sehingga mereka dapat fokus terhadap konten-konten sejenis yang akan laku di pasar. Dimensi kedua dilihat dari penetrasi proses komodifikasi yang sedang terjadi dalam masyarakat ke dalam proses dan institusi komunikasi sehingga perkembangan proses komodifikasi itu memengaruhi komunikasi sebagai praktik sosial (Mosco, 2009). Mosco (2009) memberikan contoh bahwa kecenderungan dunia internasional untuk melakukan liberalisasi dan privatisasi perusahaan pada tahun 1980 -an membuat institusi telekomunikasi dan media publik dan pemerintah yang sebelumnya memiliki komitmen sosial untuk memberikan akses yang luas dan konten yang merefleksikan beragam elemen dalam masyarakat menjadi sebuah saluran komunikasi komersial yang memberikan akses pada khalayak yang dapat menjangkaunya dan memberikan konten yang dapat menyalurkan khalayak pada pengiklan.

Komodifikasi dalam industri komunikasi memiliki lima bentuk, yaitu komodifikasi konten, komodifikasi khalayak, komodifikasi pekerja, komodifikasi imanen, dan komodifikasi perluasan (externalizing commodification) (Mosco, 2009). Komodifikasi konten meliputi proses transformasi pesan ke sistem makna, lalu menjadi produk yang dapat dipasarkan (Mosco, 2009). Produk komunikasi sebagai sebuah komoditi tidak hanya menghasilkan nilai tambah berupa keuntungan finansial, tetapi juga memberikan keuntungan lain bagi pemilik modal, 
yakni pembentukan dan penyebaran pesan-pesan yang mendukung kepentingan pemilik modal (Mosco, 2009).

Media-media baru di era digital memberi kesempatan para pemilik modal untuk melakukan komodifikasi konten dengan cara yang lebih beragam (Mosco, 2009). Konten dapat disebarkan melalui berbagai macam medium yang berbeda, seperti TV terestrial, TV kabel, dan situs streaming dengan paket akses berbayar yang juga beragam, misalnya paket berbayar berdasarkan waktu langganan (subscription), jumlah tampilan (pay-per-view), dan jumlah konten (pay-per-content). Para pemilik modal dapat memonitor dan mengukur konten mana yang paling menguntungkan sehingga mereka dapat fokus terhadap konten tersebut. Proses komodifikasi konten didukung oleh regulasi mengenai hak atas kekayaan intelektual yang memungkinkan pemilik konten mengontrol penggunaan konten dan format konten melalui lisensi (Mosco, 2009).

Bentuk komodifikasi yang kedua adalah komodifikasi khalayak. Pengukuran dan pemonitoran penyebaran dan pengaksesan konten yang dimungkinkan oleh teknologi digital membuat para perusahaan media dapat mengetahui informasi mengenai khalayak mereka dengan lebih tepat, seperti informasi mengenai karakteristik demografi, akses konten, dan transaksi pembayaran (Mosco, 2009). Informasi tersebut dapat dimanfaatkan oleh perusahaan media untuk membuat suatu ruang iklan yang tersegmen secara spesifik, lalu menawarkannya kepada para pengiklan yang ingin menargetkan produknya kepada khalayak dengan karakteristik tersebut. Dalam hal itu, khalayak menjadi komoditas yang dijual oleh perusahaan media kepada para pengiklan.

Bentuk ketiga adalah komodifikasi pekerja. Pada proses komodifikasi pekerja, kemampuan pekerja dalam membuat konsep dipisahkan dari kemampuan mereka untuk mengeksekusi konsep tersebut (Mosco, 2009). Suatu pekerjaan dibagi ke dalam beberapa bagian dengan perhitungan keefisienan waktu dan jumlah pekerja sehingga pekerja yang semula memiliki kontrol terhadap keseluruhan proses pekerjaan menjadi seperti hanya bagian dari sebuah mesin (Mosco, 2009). Bagian konseptualisasi dialihkan ke kelas manajerial yang merupakan bagian dari para pemilik modal atau pihak-pihak yang merepresentasikan kepentingan para pemilik modal (Mosco, 2009).

Bentuk keempat adalah komodifikasi imanen atau komodifikasi suatu produk yang dihasilkan dari suatu proses pembuatan komoditas lain (Mosco, 2009). Contohnya adalah rating penonton. Pemonitoran dan pengukuran proses produksi, distribusi, pertukaran, dan konsumsi dalam industri media merupakan bagian yang tidak terpisahkan dari proses komodifikasi konten dan khalayak. Pemonitoran dan pengukuran tersebut menghasilkan informasi, seperti karakteristik demografi khalayak, data penjualan, dan pola perilaku konsumen yang menjadi bagian penting dalam proses pembentukan komoditas lain. Misalnya, rating penonton dalam industri pertelevisian menjadi pertimbangan stasiun televisi dalam membuat suatu konten tertentu atau menjadi pertimbangan para pengiklan untuk memasang iklan pada waktu tertentu.

Bentuk kelima adalah komodifikasi perluasan atau komodifikasi hal-hal yang sebelumnya tidak tersentuh oleh proses komodifikasi (Mosco, 2009). Beberapa contoh komodifikasi perluasan adalah komersialisasi informasi publik, perubahan area publik menjadi area yang dikelola swasta, peningkatan ketergantungan acara-acara festival pada sponsor komersial, dan pembayaran jasa untuk menjaga privasi (Mosco, 2009).

Dalam sektor penyiaran olahraga di televisi, dua komoditas utama yang dihasilkan adalah konten dan khalayak (Milne, 2016). Komoditas konten berupa program acara yang diproduksi atau diperoleh dan kemudian ditayangkan pada waktu tertentu, sedangkan komoditas khalayak berupa khalayak yang memilih untuk menonton program acara tertentu (Milne, 2016). Oleh karena itu, titik awal fokus penelitian mengenai komodifikasi di sektor penyiaran olahraga adalah komodifikasi konten dan komodifikasi khalayak.

Penelusuran mengenai proses komodifikasi dalam industri media perlu dimulai dari pemahaman mengenai aktivitas di dalam industri media. Menurut Gillian Doyle (2002), inti dari industri media adalah menyalurkan konten kepada khalayak dengan tujuan membuat kekayaan intelektual, mengemasnya, dan memaksimalkan keuntungan dengan menjualnya 
sebanyak mungkin ke seluas mungkin khalayak dengan harga yang setinggi mungkin. Doyle (2002) membagi aktivitas di industri media ke dalam dua tahapan besar, yaitu upstream dan downstream. Upstream merupakan tahapan awal dalam proses produksi, yakni tahap pembuatan konten. Tahapan selanjutnya adalah downstream yang terdiri atas tahap pengemasan di mana konten digabung dan dikemas menjadi suatu produk yang dapat dipasarkan, dan tahap distribusi di mana produk media disalurkan kepada khalayak.

Kerangka alur aktivitas industri media yang dipaparkan oleh Doyle (2002) tersebut diadaptasi oleh Milne (2016) untuk menjelaskan alur aktivitas penyiar media terkait hak siar siaran olahraga. Milne (2016) menjelaskan bahwa pada tahap upstream, hak kekayaan intelektual berupa hak siar itu dibuat atau diperoleh, kemudian pada tahap downstream, konten media berupa program-program televisi dibuat dan didistribusikan atau ditransmisikan kepada khalayak melalui saluran-saluran yang dimiliki oleh penyiar. Perolehan keuntungan dari hak siar yang dimiliki dapat berasal dari berbagai cara tergantung dari jenis penyiaran atau model bisnisnya, seperti televisi terestrial komersial, lembaga penyiaran publik terestrial, televisi berbayar, layanan berbayar online, dan layanan berbayar pada platform mobile dengan beragam skema akses, seperti gratis, berbayar, atau bayar per tayangan (Milne, 2016).

\section{TEMUAN DAN DISKUSI}

\section{TVRI dan Siaran Olahraga}

Hubungan TVRI dengan dunia olahraga telah ada sejak awal TVRI berdiri. TVRI mengudara secara resmi pada tanggal 24 Agustus 1962 dengan menyiarkan secara langsung upacara pembukaan Asian Games 1962 di Stadion Gelora Bung Karno Jakarta. Saat itu TVRI belum berbentuk lembaga penyiaran publik seperti sekarang. Pada era kepemimpinan Presiden Sukarno dan Presiden Suharto, TVRI merupakan televisi pemerintah yang diintervensi secara politik untuk kepentingan pemerintah yang sedang berkuasa (Masduki, 2017). TVRI menjadi alat untuk menjangkau rakyat di seluruh pelosok Indonesia dan digunakan untuk menayangkan siaran olahraga yang dinilai mampu membangkitkan rasa nasionalisme dan kesatuan rakyat (Masduki, 2017). Untuk memperkuat TVRI sebagai alat negara, TVRI mendapatkan pembiayaan yang besar dari negara dan memiliki pegawai-pegawai negeri yang loyal, serta monopoli atas siaran olahraga di Indonesia (Masduki, 2017).

Setelah reformasi politik tahun 1998, kebijakan media di Indonesia menjadi lebih liberal (Masduki, 2017). Persaingan antarstasiun televisi komersial untuk mendapatkan keuntungan dari iklan semakin meningkat dan kepemilikan media semakin terpusat pada beberapa konglomerat (Armando, 2014). TVRI yang semula merupakan televisi pemerintah berubah status menjadi Lembaga Penyiaran Publik berdasarkan UU No. 32 Tahun 2002 tentang Penyiaran, sebagai konsekuensinya perubahan status tersebut menjadikan pendanaan dari negara untuk TVRI menjadi berkurang, selain itu TVRI juga kehilangan monopolinya terhadap siaran olahraga akibat persaingan terbuka dengan televisi-televisi komersial. Kedua hal tersebut menyebabkan TVRI semakin kehilangan penontonnya yang memilih beralih ke televisi-televisi komersial (Masduki, 2017).

Usaha untuk menarik penonton agar kembali menonton TVRI dengan menggunakan siaran olahraga dilakukan TVRI pada tahun 2012. Selain membeli hak siar untuk kejuaraan tinju dunia dan Olimpiade 2012, TVRI juga membeli hak siar free-to-air Liga Italia Seri A untuk tiga musim pertandingan dari agensi MP dan Silva Singapura (Masduki, 2017). Menurut Masduki (2017), keputusan TVRI membeli hak siar Liga Italia Seri A itu didasarkan pada pengalaman TVRI ketika memiliki monopoli hak siar Piala Dunia pada tahun 1980-an dan kesuksesan televisi-televisi swasta dalam meningkatkan jumlah penonton dan pendapatan iklan melalui siaran liga sepak bola. Keputusan itu mendapatkan kritik dari sejumlah pihak karena TVRI dianggap telah melanggar tugasnya sebagai lembaga penyiaran publik yang seharusnya berpihak pada kepentingan publik dan seharusnya menjalankan peranan budaya untuk meningkatkan kesadaran publik tentang pemain-pemain sepak bola Indonesia dan prestasi-prestasi mereka dengan memprioritaskan acara -acara sepak bola nasional di jam prime time dibandingkan liga sepak bola luar negeri (Masduki, 
2017). Dengan menayangkan Liga Italia di jam prime time, TVRI dituding telah bergeser ke arah kepentingan komersial dan pada akhirnya, usaha TVRI untuk menaikkan jumlah penonton melalui siaran Liga Italia Seri A itu mengalami kegagalan (Masduki, 2017). Penayangan Liga Italia Seri A di TVRI itu dihentikan di tengah jalan karena adanya permasalahan izin dalam kontrak pembelian hak siar (Nurhasim, 2014).

\section{Siaran Liga Primer Inggris di TVRI}

Usaha untuk membuat khalayak kembali menonton TVRI dengan menggunakan siaran olahraga kembali dilakukan pada masa kepemimpinan Direktur Utama Helmy Yahya. Di bawah kepemimpinan Helmy Yahya, terjadi peningkatan penayangan pertandingan olahraga di TVRI, terutama pertandingan bulu tangkis dan sepak bola (CNN Indonesia, 2019). Pemilihan kedua cabang olahraga tersebut didasarkan pada pertimbangan bahwa kedua olahraga tersebut adalah olahraga yang paling populer dan paling banyak ditonton di Indonesia (Dhyaksa, 2019; Petriella, 2019).

Pada periode kepemimpinan Helmy Yahya, TVRI mendapatkan hak siar sepuluh turnamen bulu tangkis internasional, dan sejumlah pertandingan sepak bola internasional, seperti English Football League Championship, Coppa Italia, Carabao Cup, dan Liga Primer Inggris (CNN Indonesia, 2019). Di antara siaran pertandingan-pertandingan olahraga yang ditayangkan oleh TVRI itu, Liga Primer Inggris menjadi siaran pertandingan yang paling diunggulkan untuk mengangkat rating TVRI dan membuat banyak orang kembali menonton TVRI dibandingkan dengan siaran pertandingan-pertandingan yang lain. Hal itu terlihat dari sebutan Monster Program yang diberikan oleh Helmy Yahya kepada Liga Primer Inggris (Dhyaksa, 2019; Husaini, 2019).

TVRI memperoleh hak siar Liga Primer Inggris untuk musim pertandingan 2019/2020 dengan cara menjalin kerja sama dengan Mola TV selaku pemegang hak siar Liga Primer Inggris di Indonesia hingga tahun 2022 (Soenarso, 2019). Pada musim pertandingan 2019/2020, TVRI dapat menyiarkan dua pertandingan Liga Primer Inggris secara free-to-air melalui kanal analog dan digital setiap Sabtu dan Minggu dengan total 76 siaran pertandingan selama satu musim
(Petriella, 2019).

Kerja sama TVRI dengan Mola TV terjalin karena beberapa alasan. Direktur Utama Helmy Yahya mengungkapkan bahwa jaringan pertemanan dan hubungan yang baik dengan pengurus Mola TV menjadi salah satu alasan (Dhyaksa, 2019; Husaini, 2019). Selain itu, jangkauan luas TVRI dan rekam jejak kepatuhan TVRI dalam menjaga siaran dari kebocoran jaringan juga menjadi alasan Mola TV memilih bekerja sama dengan TVRI (Dhyaksa, 2019; Husaini, 2019; Petriella, 2019). Dari segi jangkauan, TVRI memiliki keunggulan dibandingkan televisi-televisi lain di Indonesia. Sebagai sebuah LPP, TVRI harus menjangkau sebanyak mungkin orang dan menjangkau seluas mungkin wilayah Indonesia (Husaini, 2019). Untuk memenuhi kewajiban tersebut, TVRI dilengkapi dengan 360 pemancar yang telah menjangkau 160 juta penonton di seluruh Indonesia (Husaini, 2019). Jumlah pemancar tersebut berbeda jauh dengan televisi swasta yang paling banyak hanya memiliki 58 pemancar (Husaini, 2019).

Direktur Utama TVRI Helmy Yahya menyebutkan bahwa kerja sama TVRI dengan Mola TV merupakan sebuah kesepakatan bisnis (Husaini, 2019), tetapi menurutnya, kerja sama itu masih merupakan bagian dari layanan publik karena olahraga sudah menjadi kebutuhan publik (Petriella, 2019). Kerja sama dengan pihak-pihak lain seperti kerja sama dengan Mola TV tersebut merupakan bagian dari usaha untuk melakukan perubahan di TVRI (Husaini, 2019). Kerja sama dengan pihak lain itu harus dilakukan oleh TVRI karena keterbatasan anggaran yang dimiliki oleh TVRI (Husaini, 2019). Sekitar delapan puluh persen sumber pendanaan TVRI berasal dari Anggaran Pendapatan dan Belanja Negara (APBN) (Mulyana, 2018). Dalam APBN tahun anggaran 2019, TVRI mendapatkan pagu anggaran sebesar Rp951 miliar (Kementerian Keuangan Republik Indonesia, 2019). Menurut Helmy Yahya, sebagian besar anggaran tersebut terpakai untuk membayar gaji karyawan (Husaini, 2019). Jika dibandingkan dengan televisi swasta, anggaran TVRI saat ini hanya cukup untuk produksi program di televisi swasta selama 2-3 minggu (Husaini, 2019). 


\section{Komodifikasi Siaran Liga Primer Inggris}

Perolehan hak siar Liga Primer Inggris disebut oleh Direktur Utama TVRI Helmy Yahya sebagai strategi TVRI untuk meningkatkan rating, jumlah penonton, dan pendapatan TVRI (Petriella, 2019). Detail skema dan nilai kerja sama TVRI dengan Mola TV sebagai pemegang hak siar Liga Primer Inggris di Indonesia tidak dibuka secara jelas ke publik (Dhyaksa, 2019; Petriella, 2019), tetapi beberapa laporan perubahan di TVRI setelah penayangan Liga Primer Inggris yang dibuka ke publik dan observasi langsung saat penayangan Liga Primer Inggris di TVRI dapat memberikan gambaran mengenai komodifikasi siaran Liga Primer Inggris di TVRI sebagai hasil dari kerja sama TVRI dan Mola TV.

Kerja sama antara TVRI dan Mola TV terkait hak siar Liga Primer Inggris itu membawa keuntungan bagi kedua belah pihak. Bagi TVRI, keberadaan siaran Liga Primer Inggris di TVRI mampu menarik masyarakat untuk kembali menonton TVRI. Setelah adanya siaran Liga Primer Inggris, rating TVRI meningkat menjadi 10, dari yang sebelumnya berada di posisi 15 (Husaini, 2019). Ketika TVRI menayangkan pertandingan besar, share TVRI meningkat menjadi 8,4 (Husaini, 2019). Keberadaan siaran Liga Primer Inggris juga meningkatkan penghasilan TVRI dari iklan (Husaini, 2019). Slot iklan selama penayangan Liga Primer Inggris telah terisi penuh (Dhyaksa, 2019; Husaini, 2019).

Bagi Mola TV, kerja sama dengan TVRI itu juga membawa keuntungan, antara lain dari segi jaringan, kekuatan pemancar, dan infrastruktur (Kusuma, 2019). Mola TV atau PT Global Media Visual merupakan perusahaan media multiplatform yang tergabung dalam Grup Djarum (Kriesdinar, 2019; Widi \& Arbar, 2019). Mola TV termasuk perusahaan yang baru beroperasi di Indonesia (Dhyaksa, 2019) dan belum banyak orang yang mengenalnya (Kusuma, 2019) sehingga kerja sama dengan TVRI yang memiliki jaringan luas dapat membantu Mola TV untuk lebih dikenal di Indonesia. Hal itu antara lain dapat dilakukan melalui iklan di antara segmen acara dan peletakan logo Mola TV di samping logo TVRI pada bagian pojok kanan atas selama siaran pertandingan Liga Primer Inggris berlangsung.

Kepemilikan hak siar Liga Primer Inggris di TVRI tidak hanya membuat TVRI dapat menayangkan pertandingan langsung (live) dalam program Matchday, tetapi juga membuat TVRI dapat memproduksi program-program lain terkait Liga Primer Inggris yang ditayangkan sebelum pertandingan, saat jeda antarbabak, dan setelah pertandingan langsung berakhir. Program-program acara tersebut menyediakan kesempatan lebih banyak bagi TVRI untuk menerima iklan dan sponsor melalui berbagai macam cara.

Terdapat lima sponsor utama yang muncul dalam daftar sponsor saat siaran Liga Primer Inggris di TVRI, yaitu Polytron, BCA, tiket.com, Super Soccer TV, dan blibli.com. Kelima sponsor tersebut merupakan bisnis di bawah Grup Djarum, grup yang juga membawahi Mola TV (Widi \& Arbar, 2019). Kelima sponsor utama tersebut menjadi sponsor nama program acara, seperti BCA Pregame Show yang ditayangkan sebelum pertandingan berlangsung; Polytron Halftime Show dengan segmen Super Soccer TV Highlights Reel, Polytron Players to Watch, BCA Match Outlook, Blibli.com Keys to Success, dan Tiket.com Stadium Cam yang ditayangkan saat jeda antarbabak; dan Polytron Wrapup Show yang ditayangkan setelah pertandingan langsung berakhir. Selain menjadi sponsor berupa nama program acara dan segmen acara, mereka juga memasang iklan saat jeda antarsegmen program, logo di layar latar belakang selama acara berlangsung, logo di properti acara, logo di daftar sponsor acara pada akhir acara, dan ad lib atau penyebutan nama sponsor oleh pembawa acara. Saat pertandingan sedang berlangsung, spot untuk iklan juga muncul di bawah penanda waktu dan skor.

Siaran Liga Primer Inggris di TVRI dibuat menjadi sebuah komoditas yang menguntungkan bagi TVRI dan Mola TV sebagai pemegang hak siar Liga Primer Inggris di Indonesia. Kedua belah pihak menjaga keeksklusifan hak siar yang mereka miliki dengan memastikan tidak ada kebocoran jaringan. Situs -situs live streaming yang biasanya menayangkan siaran TVRI secara gratis, seperti situs resmi TVRI, Vidio, MeTube, dan UseeTV, tidak menayangkan siaran TVRI saat pertandingan Liga Primer Inggris 
berlangsung karena siaran Liga Primer Inggris di TVRI hanya boleh ditonton melalui antena biasa (Kusuma, 2019). Mola TV bahkan melaporkan ke polisi situssitus yang tetap menayangkan streaming Liga Primer Inggris tanpa izin (Kriesdinar, 2019). Proses memperoleh hak siar dan menjaga keeksklusifan hak siar tersebut merupakan bagian dari tahap upstream dalam alur aktivitas media terkait hak siar menurut Milne (2016).

Pada tahap downstream, siaran Liga Primer Inggris dikemas ke dalam beberapa program acara yang dibuat untuk menarik, membangun, dan mempertahankan perhatian penonton terhadap pertandingan Liga Primer Inggris. Sebelum acara berlangsung, terdapat program acara BCA Pregame Show yang membahas prediksi jalannya pertandingan yang akan berlangsung. Saat jeda antarbabak, terdapat program acara Polytron Halftime Show yang membahas pertandingan babak pertama dan prediksi babak kedua. Setelah pertandingan berakhir, terdapat program acara Polytron Wrapup Show dan Post Match yang membahas jalannya pertandingan dari babak satu hingga babak dua. Dengan konten siaran Liga Primer Inggris, TVRI berusaha menaikkan jumlah penonton dan durasi mereka menonton TVRI. Para pengiklan dan sponsor melihat potensi dari penonton Liga Primer Inggris di TVRI sehingga mereka memasang iklan dan menjadi sponsor saat penayangan program-program acara Liga Primer Inggris. Penonton Liga Primer Inggris tidak lagi hanya sekadar menonton siaran olahraga, tetapi juga menjadi komoditas yang dapat ditawarkan kepada para pengiklan dan sponsor. Siaran Liga Primer Inggris juga tidak hanya sekadar dikemas untuk menjadi hiburan bagi masyarakat, tetapi juga dikemas supaya dapat mengakomodasi para pihak yang ingin memasang iklan dan menjadi sponsor.

Sebagai sebuah Lembaga Penyiaran Publik, TVRI diperkenankan menerima pendapatan dari iklan. Pendapatan dari iklan tersebut akan masuk ke kas negara melalui jalur Penerimaan Negara Bukan Pajak (PNBP) (Dhyaksa, 2019; Husaini, 2019). Pendapatan tambahan di luar APBN itu menjadi salah satu solusi bagi permasalahan keterbatasan anggaran yang dihadapi TVRI di tengah usaha TVRI untuk bertransformasi menjadi lebih baik. Meskipun demikian, sebagai sebuah televisi publik, TVRI tidak boleh berubah menjadi berorientasi komersial seperti televisi-televisi swasta karena prinsip dasar keduanya berbeda. Menurut Masduki dan Darmanto (2014), Lembaga Penyiaran Publik tidak seharusnya bersaing dengan Lembaga Penyiaran Komersial dalam hal rating dan komersialisasi. Jika sebuah lembaga penyiaran mengutamakan rating dan pendapatan dari iklan, program acara akan diperlakukan sebagai barang dagangan dan hanya program-program acara yang menguntungkan yang akan diutamakan (Masduki \& Darmanto, 2016). Lembaga Penyiaran Publik harus mampu memenuhi kebutuhan semua warga negara dan tidak boleh hanya mengutamakan program-program yang memiliki rating tinggi dan memberikan keuntungan finansial (Masduki \& Darmanto, 2016). Untuk mencegah perubahan orientasi televisi publik menjadi komersial, perlu adanya penyeimbangan antara tuntutan perubahan TVRI menjadi televisi publik yang lebih baik dengan anggaran yang diberikan kepada TVRI.

\section{KESIMPULAN}

Komodifikasi siaran olahraga di TVRI telah terjadi sejak pertama kali TVRI memulai siaran. Pada saat itu TVRI masih merupakan televisi pemerintah yang mengalami intervensi politik. Siaran olahraga di TVRI digunakan oleh pemerintah yang berkuasa untuk membangkitkan nasionalisme dan rasa persatuan warga negara.

Ketika TVRI berubah bentuk menjadi Lembaga Penyiaran Publik setelah masa reformasi, siaran olahraga masih menjadi sebuah komoditas, tetapi untuk tujuan yang berbeda. Setelah reformasi, TVRI mengalami penurunan jumlah anggaran dari pemerintah. Dengan anggaran yang terbatas, TVRI tidak mampu bersaing dengan televisi-televisi swasta sehingga jumlah penonton TVRI juga mengalami penurunan. Siaran olahraga yang digemari oleh masyarakat menjadi salah satu solusi bagi permasalahan-permasalahan tersebut.

Siaran olahraga populer, seperti Liga Primer 
Inggris, digunakan untuk menarik perhatian khalayak supaya kembali menonton TVRI. Siaran olahraga itu dikemas ke dalam beberapa program acara yang dapat mendorong khalayak untuk menonton TVRI dalam durasi yang lebih lama. Program-program acara tersebut juga dikemas supaya mampu menyediakan lebih banyak tempat bagi para pengiklan dan sponsor.

Sebagai sebuah televisi publik, TVRI tidak dilarang untuk menerima iklan. Pendapatan tambahan dari iklan dapat menjadi solusi bagi masalah keterbatasan anggaran yang dimiliki oleh TVRI. Meskipun demikian, tarif iklan di TVRI memiliki batasan yang diatur oleh Peraturan Pemerintah Nomor 13 Tahun 2005 sehingga pendapatan TVRI dari iklan tidak dapat sebesar pendapatan iklan di televisi-televisi swasta.

Permasalahan keterbatasan anggaran yang dihadapi oleh TVRI harus menjadi perhatian bagi para pemangku kepentingan. Dengan anggaran yang terbatas, TVRI akan mengalami kesulitan melakukan usaha-usaha untuk berubah menjadi televisi publik yang lebih baik. Pendapatan dari iklan dapat menjadi solusi, tetapi hal itu harus dilakukan dengan hati-hati supaya TVRI tidak bergeser menjadi berorientasi komersial. TVRI harus dapat tetap memegang prinsip Lembaga Penyiaran Publik yang harus memenuhi kebutuhan semua warga negara. TVRI tidak boleh hanya mengutamakan program-program yang mampu menaikkan jumlah penonton dan pendapatan saja.

\section{DAFTAR PUSTAKA}

Armando, A. (2014). The greedy giants: Centralized television in post-authoritarian Indonesia. International Communication Gazette, 76(4-5), 390406. https://doi.org/10.1177/1748048514524106

Bellamy, R. V. (2006). Sports Media: A Modern Institution. In A. A. Raney \& J. Bryant (Ed.), Handbook of Sports and Media (hal. 66-79). Lawrence Erlbaum Associates.

CNN Indonesia. (2019). Langkah Perubahan TVRI Kala Dipimpin Helmy Yahya. Diambil 26 Desember 2019, dari https:// www.cnnindonesia.com/

hiburan/20191205200935-241-454572/langkah-

perubahan-tvri-kala-dipimpin-helmy-yahya

Dhyaksa, A. (2019). Helmy Yahya: Saya tidak percaya TVRI dapat Liga Inggris. Diambil 2 November 2019, dari https://beritagar.id/artikel/berita/helmy -yahya-saya-tidak-percaya-tvri-dapat-liga-inggris

Dyatmika, T. (2015). Tayangan Televisi dan Sepak Bola di Indonesia : Tinjauan Ekonomi Politik Media Pada Penyiaran Televisi Indonesia. Konvergensi: jurnal ilmiah ilmu komunikasi, 1(1), 53 -69 .

Doyle, G. (2002). Understanding Media Economics. London: Sage Publications.

Enga, A. H. (2017). Komodifikasi Pernikahan "Menuju Janji Suci "Di Trans Tv. Interaksi: Jurnal Ilmu Komunikasi, 5(2), 177-186.

Husaini, A. (2019). Wawancara Presdir TVRI Helmy Yahya, dari kelakuan netizen sampai reformasi total TVRI. Diambil 2 November 2019, dari https://industri.kontan.co.id/news/wawancarapresdir-tvri-helmy-yahya-dari-kelakuan-netizensampai-reformasi-tvri-total

Junaedi, F., Nugroho, H., \& Wahyono, S.B. (2018). Komodifikasi Bonek dalam Jejaring Konglomerasi Jawa Pos. Jurnal ASPIKOM, 3(5), 891-902.

Kementerian Keuangan Republik Indonesia. (2019). Buku II Nota Keuangan Beserta Anggaran Pendapatan dan Belanja Negara Tahun Anggaran 2019.

Kriesdinar, M. (2019). Mola TV Perkarakan 7 Situs Pelaku Live Streaming Ilegal Liga Inggris, Ini Daftarnya. Diambil 28 Desember 2019, dari https://jogja.tribunnews.com/2019/12/20/mola-tv -perkarakan-7-situs-pelaku-live-streaming-ilegalliga-inggris-ini-daftarnya

Kusuma, A. (2019). Apa Itu Mola TV dan Bagaimana Cara Menonton Premier League di Sana? Diambil 28 Desember 2019, dari https:// kumparan.com/kumparanbola/apa-itu-mola-tvdan-bagaimana-cara-menonton-premier-league-di -sana-1rJvr6Xzi2t 
Lubis, M. (2018). Belanja Iklan Januari-September 2018 Tumbuh 5 Persen. Diambil 29 November 2019, dari https://www.nielsen.com/id/en/pressreleases/2018/belanja-iklan-januari-september2018-tumbuh-5-persen/

Masduki. (2017). Political economy of sport broadcasting: Assessing Indonesian PSB policy in sport broadcasting. International Communication $\mathrm{Ga}$ zette, 79(2), 162-174. https:// doi.org/10.1177/1748048516689196

Masduki, \& Darmanto. (2014). \#Save RRI-TVRI: Dokumen Inisiatif Publik untuk Transformasi Lembaga Penyiaran Publik di Indonesia. Jakarta: Rumah Perubahan Lembaga Penyiaran Publik (RPLPP).

Masduki, \& Darmanto. (2016). Penyiaran Publik: Regulasi dan Implementasi. Yogyakarta: Rumah Perubahan Lembaga Penyiaran Publik (RPLPP).

Milne, M. (2016). The Transformation of Television Sport: New Methods, New Rules. Hampshire: Palgrave Macmillan.

Mosco, V. (2009). The Political Economy of Communication. The Political Economy of Communication ( 2 ed.). London: Sage Publications.

Mulyana, R. N. (2018). TVRI sulit imbangi persaingan bisnis industri televisi dalam negeri. Diambil 28 November 2019, dari https:// industri.kontan.co.id/news/tvri-sulit-imbangipersaingan-bisnis-industri-televisi-dalam-negeri

Nurhasim. (2014). Mengapa TVRI Tak Siarkan Liga Italia Serie A. Diambil 12 Desember 2019, dari https://nasional.tempo.co/read/543498/mengapatvri-tak-siarkan-liga-italia-serie-a/

Petriella, Y. (2019). Arti Premier League Bagi TVRI. Diambil 19 November 2019, dari https:// ekonomi.bisnis.com/read/20190626/12/937971/ arti-premier-league-bagi-tvri.

Puspa, A. W. (2019). Pendapatan MNCN Bisa Ditunjang Kenaikan Biaya Iklan. Diambil 10 Desember 2019, dari https://market.bisnis.com/ $\mathrm{read} / 20190316 / 7 / 900453 /$ pendapatan-mncn-bisaditunjang-kenaikan-biaya-iklan
Putra, A. M., Heru Nugroho, Budiawan (2016) Ekonomi Politik Pemberitaan Konflik Persepakbolaan Indonesia. Jurnal Ilmu Komunikasi, 13 (2), 213-232.

Rahardjo, R. P. E. (2018). Komodifikasi Madura United Football Club Dalam Pemberitaan Harian Pagi Kabar Madura. e-Journal Universitas Tribuana Kalabahi, 1(1), 211-211.

Sanjaya, M. (2020). Praktik Ekonomi Politik Media Pada Tayangan Liga Inggris di TVRI. Perspektif Komunikasi: Jurnal Ilmu Komunikasi Politik dan Komunikasi Bisnis, 4(1), 30-39.

Soenarso, S. A. (2019). TVRI Ikut Siarkan Pertandingan Liga Inggris Musim Depan. Diambil 14 November 2019, dari https://insight.kontan.co.id/ news/tvri-ikut-siarkan-pertandingan-liga-inggrismusim-depan

Taylor, G., \& Thomass, B. (2017). Sports rights and public service media/public broadcasting: Case studies on economic and political implications. International Communication Gazette, 79(2), 111 -119 .

https:// doi.org/10.1177/1748048516689190

The Associated Press. (2019). English Premier League broadcast rights rise to $\$ 12$ billion. Diambil 28 November 2019, dari https://apnews.com/ c720239949584d478eb4b1ee7fa6f042

Ulya, H. (2019). Komodifikasi Pekerja Pada Youtuber Pemula dan Underrated (Studi Kasus YouTube Indonesia). Interaksi: Jurnal Ilmu Komunikasi, 8 (2), 1-12.

Widi, T., \& Arbar, T. F. (2019). Kisah Bambang Hartono: Punya Harta Rp522 T \& Hobi Jajan! Diambil 26 Desember 2019, dari https:// www.cnbcindonesia.com/ market/20191208083257-17-121235/kisahbambang-hartono-punya-harta-rp522-t-hobi-jajan 